\title{
Reduced Expression of the PP2A Methylesterase, PME-1, or the PP2A Methyltransferase, LCMT-1, Alters Sensitivity to Beta-Amyloid-Induced Cognitive and Electrophysiological Impairments in Mice
}

\author{
Agnieszka Staniszewski, ${ }^{1,2}$ Hong Zhang, ${ }^{1,2}$ Kesava Asam, ${ }^{1,2}$ Rose Pitstick, ${ }^{3}$ Michael P. Kavanaugh, ${ }^{3}$ \\ Ottavio Arancio, ${ }^{1,2,4}$ and Russell E. Nicholls ${ }^{1,2}$ \\ ${ }^{1}$ Department of Pathology and Cell Biology, Columbia University, New York, New York 10032, ${ }^{2}$ Taub Institute for Research on Alzheimer's Disease \\ and the Aging Brain, Columbia University, New York, New York 10032, ${ }^{3}$ McLaughlin Research Institute, Great Falls, Montana 59405, and \\ ${ }^{4}$ Department of Medicine, Columbia University, New York, New York 10032
}

Beta-amyloid $(\mathrm{A} \beta)$ is thought to play a critical role in Alzheimer's disease (AD), and application of soluble oligomeric forms of $\mathrm{A} \beta$ produces $\mathrm{AD}$-like impairments in cognition and synaptic plasticity in experimental systems. We found previously that transgenic overexpression of the PP2A methylesterase, PME-1, or the PP2A methyltransferase, LCMT-1, altered the sensitivity of mice to $A \beta$-induced impairments, suggesting that PME-1 inhibition may be an effective approach for preventing or treating these impairments. To explore this possibility, we examined the behavioral and electrophysiological effects of acutely applied synthetic $\mathrm{A} \beta$ oligomers in male and female mice heterozygous for either a PME-1 KO or an LCMT-1 gene-trap mutation. We found that heterozygous PME-1 KO mice were resistant to A $\beta$-induced impairments in cognition and synaptic plasticity, whereas LCMT-1 gene-trap mice showed increased sensitivity to A $\beta$-induced impairments. The heterozygous PME-1 KO mice produced normal levels of endogenous $\mathrm{A} \beta$ and exhibited normal electrophysiological responses to picomolar concentrations of $A \beta$, suggesting that reduced PME-1 expression in these animals protects against $A \beta$-induced impairments without impacting normal physiological A $\beta$ functions. Together, these data provide additional support for roles for PME-1 and LCMT- 1 in regulating sensitivity to $\mathrm{A} \beta$-induced impairments, and suggest that inhibition of PME-1 may constitute a viable therapeutic approach for selectively protecting against the pathologic actions of $\mathrm{A} \beta$ in $\mathrm{AD}$.

Key words: Alzheimer's disease; beta-amyloid; cognitive impairment; protein methylation; protein phosphatase 2A; synaptic plasticity

Significance Statement

Elevated levels of $\beta$-amyloid $(\mathrm{A} \beta)$ in the brain are thought to contribute to the cognitive impairments observed in Alzheimer's disease patients. Here we show that genetically reducing endogenous levels of the PP2A methylesterase, PME-1, prevents the cognitive and electrophysiological impairments caused by acute exposure to pathologic concentrations of $\mathrm{A} \beta$ without impairing normal physiological $\mathrm{A} \beta$ function or endogenous $\mathrm{A} \beta$ production. Conversely, reducing endogenous levels of the PP2A methyltransferase, LCMT-1, increases sensitivity to $\mathrm{A} \beta$-induced impairments. These data offer additional insights into the molecular factors that control sensitivity to $\mathrm{A} \beta$-induced impairments, and suggest that inhibiting PME-1 may constitute a viable therapeutic avenue for preventing $\mathrm{A} \beta$-related impairments in Alzheimer's disease.

Received Dec. 12, 2019; revised Mar. 27, 2020; accepted Apr. 17, 2020.

Author contributions: A.S., H.Z., K.A., and R.E.N. performed research; A.S., H.Z., and R.E.N. analyzed data;

R.P. and M.P.K. contributed unpublished reagents/analytic tools; 0.A. and R.E.N. designed research; 0.A. edited the paper; R.E.N. wrote the paper.

This work was supported by National Institutes of Health Grant 1R01NS092045-01. We thank Dr. Benjamin Cravatt (Scripps Research Institute) for the generous gift of the PME-1 KO mice; and Dr. Peter Davies (Albert Einstein Medical College) for the generous gifts of the PHF1 and (P13 antibodies.

The authors declare no competing financial interests.

Correspondence should be addressed to Russell E. Nicholls at rn95@columbia.edu.

https://doi.org/10.1523/JNEUROSCI.2983-19.2020

Copyright $\odot 2020$ the authors

\section{Introduction}

Multiple lines of evidence suggest a role for the serine/threonine phosphatase, PP2A, in Alzheimer's disease (AD). Among these are the observations that (1) PP2A expression and activity are reduced in brains from AD patients (Gong et al., 1993, 1995; Vogelsberg-Ragaglia et al., 2001; Sontag et al., 2004); (2) reducing PP2A activity in animal models results in AD-like pathology and cognitive deficits (Kins et al., 2001; Sun et al., 2003; Schild et al., 2006; Wang et al., 2010; Yin et al., 2010; Louis et al., 2011; 
Bolognin et al., 2012); (3) PP2A is the principal phosphatase for phosphorylated forms of microtubule-associated binding protein, tau, that are linked to AD (Martin et al., 2013); and (4) pharmacological activators of PP2A have been found to reduce cognitive impairment and pathology in AD-related mouse models (Corcoran et al., 2010; van Eersel et al., 2010; Vitek et al., 2012; Basurto-Islas et al., 2014; Asam et al., 2017; Van der Jeugd et al., 2018).

PP2A is a heterotrimeric protein composed of a catalytic subunit, a structural subunit, and a regulatory subunit, and its activity is controlled, in part, through the highly regulated assembly of the multiple isoforms that exist for each of these subunits (Sents et al., 2013). One of the processes that regulates PP2A subunit assembly is C-terminal methylation of the catalytic subunit, which is catalyzed by a specific methyltransferase and methylesterase, in a process that is conserved from yeast to mammals (Sents et al., 2013). Methylation of the PP2A catalytic subunit affects its affinity for the different regulatory subunits that control the substrate specificity of the heterotrimeric holoenzyme; and in particular, methylation promotes the formation of B55 $\alpha$ subunit-containing enzymes that exhibit the highest tau phosphatase activity (Longin et al., 2007; Xu et al., 2008). In addition, dysregulated PP2A activity resulting from impaired PP2A methylation is thought to be one of the molecular mechanisms by which hyperhomocysteinemia leads to increased AD risk (Zhuo et al., 2011).

In mice, the PP2A methylesterase is encoded by the $P M E-1$ gene, and the PP2A methyltransferase is encoded by the LCMT1 gene. Consistent with the notions that decreased PP2A methylation decreases its tau phosphatase activity (Sontag and Sontag, 2014), and tau hyperphosphorylation contributes to AD-related impairments (Wang and Mandelkow, 2016), we found previously that overexpression of PME-1 in transgenic mice increased their sensitivity for $\mathrm{AD}$-related impairments resulting from acute exposure to elevated levels of $\beta$-amyloid (A $\beta$ ) (Nicholls et al., 2016). Conversely, we found that overexpression of LCMT-1 in transgenic mice protected animals from $\mathrm{A} \beta$-induced impairments (Nicholls et al., 2016). To further explore the possibility that PME-1 inhibition may constitute a viable therapeutic avenue for $\mathrm{AD}$ treatment or prevention, we sought to determine whether reducing the expression of endogenous PME-1 or LCMT-1 might also affect $\mathrm{A} \beta$ sensitivity. To do this, we used two previously described lines of mice that carry either a $\mathrm{KO}$ mutation in the PME-1 gene (Ortega-Gutierrez et al., 2008), or a gene-trap (GT) mutation in the LCMT-1 gene (MacKay et al., 2013). We tested the sensitivity of animals heterozygous for these mutations to both cognitive and electrophysiological impairments produced by acute exposure to oligomeric $\mathrm{A} \beta$ preparations and found that reduced expression of these genes altered the sensitivity of mice to $\mathrm{A} \beta$-induced impairments. These results provide further support for roles for PME-1 and LCMT-1 in regulating the pathologic response to $\mathrm{A} \beta$, and suggest that PME- 1 inhibition may be a viable therapeutic avenue for preventing or treating its pathogenic effects.

\section{Materials and Methods}

\section{Animals}

Subjects in this study were heterozygous PME-1 KO mice (OrtegaGutierrez et al., 2008), LCMT-1 GT mice (MacKay et al., 2013) (https:// www.jax.org/strain/023332), and WT control siblings. Equivalent numbers of 4- to 6-month-old male and female, heterozygous mutant and WT mice generated from crosses of heterozygous animals were used for all experiments. Animals were housed individually following surgeries to

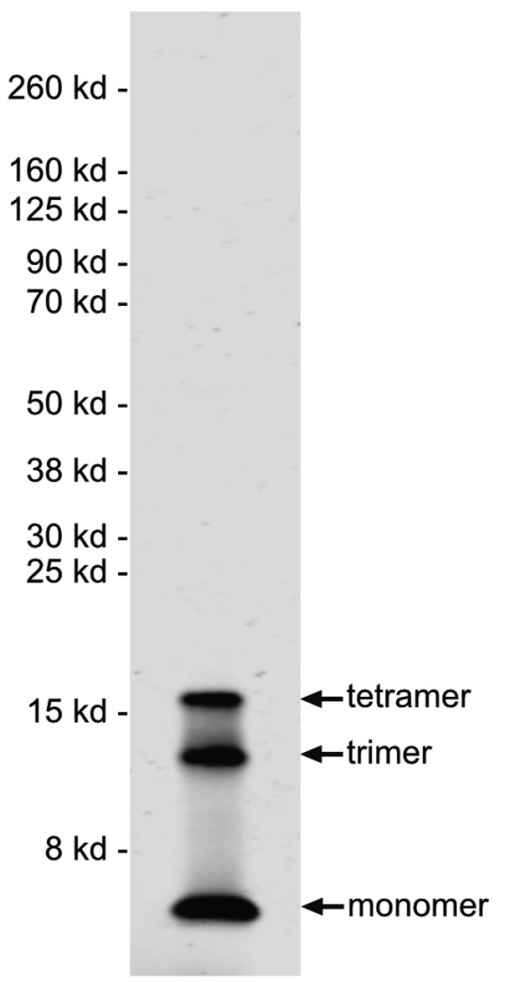

Figure 1. Representative Western blot of synthetic $A \beta$ preparations used in behavioral and electrophysiological assays. Oligomerized synthetic human $A \beta_{1-42}$ peptide was run on a 10\%-20\% Tricine gel and probed with the monoclonal antibody 6 E 10 , which recognizes an epitope contained within residues 1-17, revealing the distribution of monomeric and oligomeric species indicated. The pattern of immunoreactivity observed is consistent with that originally reported by Stine et al. (2003) and in subsequent publications (Puzzo et al., 2008; L. Lee et al., 2014; Asam et al., 2017).

implant cannulae. Surgical procedures were performed under anesthesia, and all efforts were made to minimize suffering.

\section{Experimental design and statistical analysis}

Behavioral testing was conducted during the light phase of a $12 \mathrm{~h}$ light/ dark cycle. Animals were tested in cohorts of 10-12 animals consisting of equivalent numbers of each of the genotype $\times$ treatment groups. Behavioral testing consisted a battery of tasks conducted over a period of 2 weeks in the following order: $2 \mathrm{~d}$ radial arm water maze, contextual fear conditioning, visible platform water maze, open field behavior, and sensory threshold assessment. Separate groups of 3- to 4-month-old animals were used for electrophysiological experiments and Western blotting. All procedures involving animals were conducted in strict accordance with protocols approved by the Columbia University Institutional Animal Care and Use Committee (USDA Registration \#21R-0082; AAALAC Accreditation \#000687; NYDOH \#A141). Tests for statistical significance between groups were performed using GraphPad Prism 7. In experiments involving only two groups, Student's $t$ tests were performed to test the significance of the effect of genotype. In experiments with more than two groups, regular, two-way, or two-way with repeated-measures ANOVA was performed followed by planned post hoc comparisons between groups. The details and results of all statistical tests are described in the corresponding figure legend for each experiment. Data are presented as means for each group \pm SEM.

\section{A $\beta$ treatment}

Oligomeric $\mathrm{A} \beta$ was prepared according to previously described protocols (Stine et al., 2003; Fa et al., 2010). Synthetic A $\beta$ peptide corresponding to amino acids 1-42 of human amyloid precursor protein was purchased from the UCLA Biopolymer Laboratory. The lyophilized peptide was dissolved in 1,1,1,3,3,3-hexafluoro-2-propanol, dried, and 
A

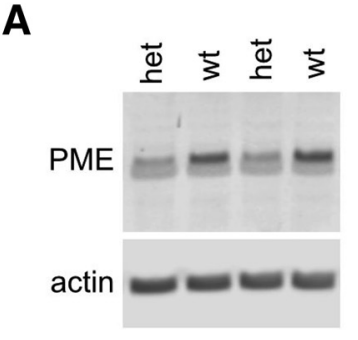

B

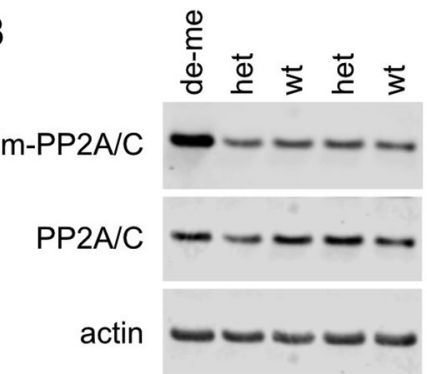

C
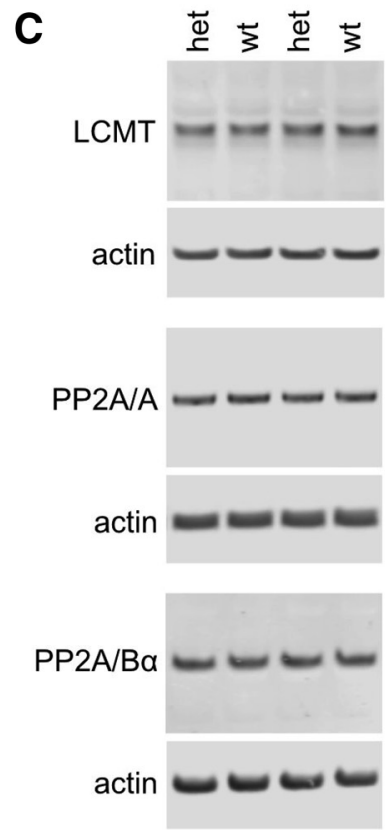

$\mathbf{E}$

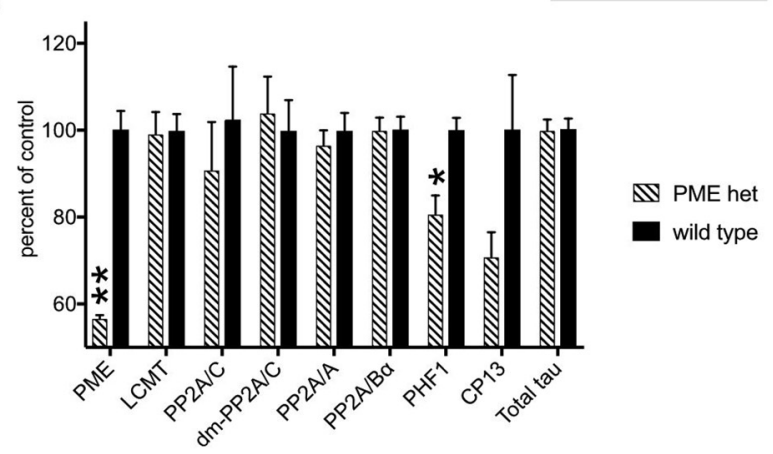

Figure 2. Heterozygous PME-1 KO mice exhibit reduced PME-1 protein expression and increased tau phosphorylation. $A$, Representative Western blot showing anti-PME-1 immunoreactivity in hippocampal homogenates from PME-1 KO heterozygotes (het) or WT sibling controls together with anti- $\beta$-actin immunoreactivity from the same lane as a loading control. B, Representative Western blot showing anti-demethyl PP2A/C immunoreactivity detected with the 1D6 monoclonal antibody in hippocampal homogenates together with the corresponding anti- $\beta$-actin immunoreactivity and total PP2A/C immunoreactivity detected after stripping and reprobing the same blot. The lane labeled "de-me" contains homogenate treated with $\mathrm{NaOH}$ to demethylate PP2A/C and serve as a positive control for the demethylspecific anit-PP2A/C antibody. C, Representative Western blots showing anti-PP2A/A, PP2A/ $\mathrm{B} \alpha$, and LCMT-1 immunoreactivity in hippocampal homogenates from PME-1 KO heterozygotes (het) or WT sibling controls together with corresponding same-lane anti- $\beta$-actin immunoreactivity as a loading control. $\boldsymbol{D}$, Representative Western blots showing anti-tau phospho S396/404 (PHF1) and anti-tau phospho S202 (CP13) together with corresponding total tau immunoreactivity from the same lane, and anti-total tau together with corresponding anti- $\beta$-actin immunoreactivity. $\boldsymbol{E}$, Histogram of mean immunoreactivity ( \pm SEM) for the indicated proteins normalized to within-lane anti- $\beta$-actin immunoreactivity (total PP2A/C resuspended to $5 \mathrm{~mm}$ in dimethyl sulfoxide by bath sonication for $10 \mathrm{~min}$. Aliquots were stored at $-20^{\circ} \mathrm{C}$. Before use, aliquots were diluted in aCSF to $100 \mu \mathrm{M}$ and incubated for $24 \mathrm{~h}$ at $4^{\circ} \mathrm{C}$. This procedure yielded a mixture of oligomeric $\mathrm{A} \beta$ species, as shown in Figure 1, that is consistent with previous reports (Stine et al., 2003; Puzzo et al., 2008; L. Lee et al., 2014; Asam et al., 2017). For experiments involving in vivo infusion of $\mathrm{A} \beta$, animals were implanted with a 26-gauge guide cannula (Plastics One) into the dorsal part of the hippocampi (coordinates: posterior $=$ $2.46 \mathrm{~mm}$, lateral $=1.50 \mathrm{~mm}$ to a depth of $1.30 \mathrm{~mm}$ ) (Paxinos and Franklin, 2013) under anesthesia with $20 \mathrm{mg} / \mathrm{kg}$ Avertin. Cannulas were fixed to the skull with acrylic dental cement (Paladur), and animals were allowed to recover for $6-8 \mathrm{~d}$ following surgery before behavioral testing; $1 \mu \mathrm{l}$ of $\mathrm{A} \beta$ was infused into each hippocampus at a concentration of 200 or $75 \mathrm{~nm}$ as indicated in the text, over a period of $1 \mathrm{~min}$ through cannulas connected to a microsyringe by a polyethylene tubing. After infusion, the needle was kept in place for an additional minute to allow diffusion of $\mathrm{A} \beta$ into the tissue. For experiments involving ex vivo treatment, $\mathrm{A} \beta$ was bath-applied to hippocampal slices at a concentration of 100 or 75 $\mathrm{nm}$ for $20 \mathrm{~min}$ before theta-burst stimulation (TBS) as indicated in the text.

\section{Radial arm water maze}

Testing was performed in a 120 -cm-diameter pool containing a six arm radial maze insert and filled with opaque water as described previously (Alamed et al., 2006). Mice were tested in $15 \times 1 \mathrm{~min}$ trials on each of 2 consecutive days. The location of the escape platform was held constant during testing, but the start location was pseudorandomly varied throughout. On the first day, training alternated between visible and hidden platform trials, while on the second day only hidden platform trials were conducted. Water temperature was maintained at $\sim 24^{\circ} \mathrm{C}$, and mice were dried and placed in a clean heated cage between trials to prevent hypothermia. Entries into maze arms that did not contain the escape platform were scored as errors. $\mathrm{A} \beta$ or vehicle was administered $20 \mathrm{~min}$ before, and again midway through testing on each day. Data are presented as the average number of errors committed during blocks of three training trials.

\section{Visible platform water maze}

This task was conducted in 120 -cm-diameter pool filled with opaque water, but without the partitions used for the radial arm water maze task. Training for this task was conducted over $2 \mathrm{~d}$ with three morning and three afternoon trials on each day. $\mathrm{A} \beta$ or vehicle was administered 20 min before each block of three trials on each day. Intertrial intervals were $15-20 \mathrm{~min}$, and rest periods between morning and afternoon sessions were 2-3 h. Each trial was a maximum of $120 \mathrm{~s}$ during which time the animals were required to swim to a visible escape platform located just above the water surface. Animals that did not reach the platform within the allotted time were guided to it and allowed to sit there for $15 \mathrm{~s}$ before returning to their home cage. The location of the platform was varied among four different locations such that it was not present in the same location on any two successive trials. Water temperature was maintained at $\sim 24^{\circ} \mathrm{C}$, and animals were dried and placed in a clean warmed cage after each trial to prevent hypothermia. Animal movements were recorded using a video-tracking system and time required to reach the hidden platform (latency) and swim speed were determined using Ethovision behavioral analysis software (Noldus).

$\leftarrow$

immunoreactivity for demethyl-PP2A/C or total tau immunoreactivity for PHF1 and CP13 antibodies) and expressed as percent of mean control value. All blots were performed on homogenates prepared from 7 heterozygous PME- 1 KO animals and 7 WT sibling controls and compared using unpaired $t$ tests: PME- 1 expression: $t=9.843,{ }^{* *} p<0.0001$, demethyl PP2A/C: $t=0.3559, p=0.7287, \mathrm{PP} 2 \mathrm{~A} / \mathrm{C}$ expression: $t=0.7076, p=0.4927$, PP2A/A expression: $t=0.6319, p=0.5393, \mathrm{PP} 2 \mathrm{~A} / \mathrm{B} \alpha$ expression: $t=0.0673, p=0.9474$, LCMT-1 expression: $t=0.1324, p=0.8969$, PHF1: $t=3.691,{ }^{*} p=0.0031$, CP13: $t=2.124$, $p=0.0551$, total tau: $t=0.1204, p=0.9062$ ). 
A
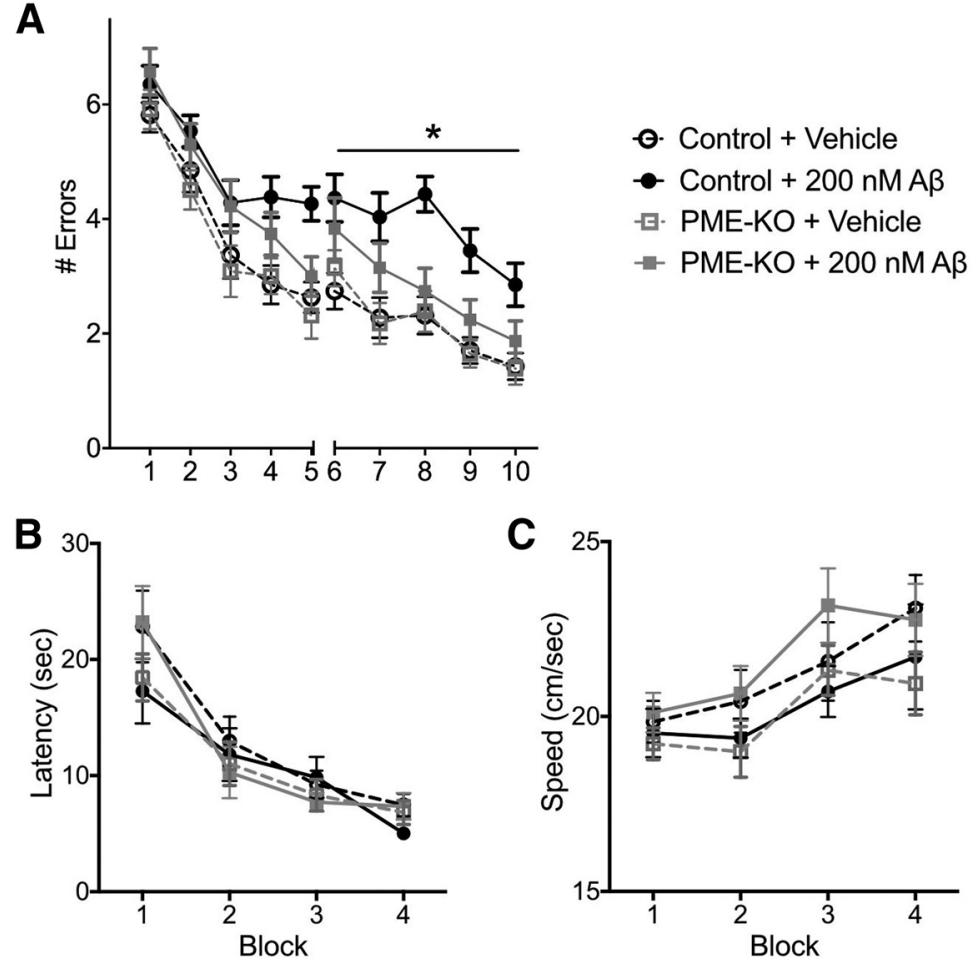

Figure 3. Heterozygous PME-KO mice are resistant to $A \beta$-induced impairments in a $2 \mathrm{~d}$ radial arm water maze task. $\boldsymbol{A}$, Plot of average number of errors committed ( \pm SEM) during each 3-trial training block of a $2 \mathrm{~d}$ radial arm water maze task for heterozygous PME-1 KO mice and WT sibling controls treated with 200 nм A $\beta$ or vehicle as indicated. Two-way repeated-measures ANOVA for errors on day 2 (blocks 6-10) with group and block as factors shows a significant effect of group $\left(F_{(3,71)}=9.028,{ }^{*} p<0.0001\right)$. Bonferroni post hoc comparisons show that $A \beta$-treated controls were significantly different from vehicle-treated controls $(p<0.0001)$, vehicle-treated PME-KO $(p<0.0001)$, and $A \beta$-treated PME-KO ( $p=0.0220)$ groups. $N=18$ control+vehicle, 20 control $+A \beta, 19 \mathrm{PME}+$ vehicle, and 18 $\mathrm{PME}+\mathrm{A} \beta, \boldsymbol{B}$, Plot of the average escape latency ( \pm SEM) for the indicated groups during training on a visible platform Morris water maze task reveals no significant differences between groups (two-way repeated-measures ANOVA for latency with group and block as factors shows no significant effect of group: $\left.F_{(3,68)}=0.4588, p=0.7120\right)$. C, Plot of the average swim speed ( \pm SEM) for the indicated groups during training on the visible platform Morris water maze task described in $\boldsymbol{B}$ reveals no significant differences between groups (two-way repeated-measures ANOVA for speed with group and block as factors shows no significant effect of group $F_{(3,68)}=1.086, p=0.3612$ ).

\section{Contextual fear conditioning}

Animals were placed into a transparent Plexiglas conditioning chamber $(33 \mathrm{~cm} \times 20 \mathrm{~cm} \times 22 \mathrm{~cm})$ (Noldus PhenoTyper). Animal movement was recorded using an overhead video camera connected to a personal computer, and freezing behavior was scored and analyzed using Ethovision XT software (Noldus). Footshocks were administered through a removable metal grid floor, and the entire apparatus was cleaned and deodorized between animals with distilled water and $70 \%$ ethanol. Animals were placed in the conditioning chamber once on each of 2 consecutive days. On the first day of exposure, mice were placed in the conditioning chamber for $2 \mathrm{~min}$ before the onset of a discrete $30 \mathrm{~s}, 2800 \mathrm{~Hz}, 85 \mathrm{~dB}$ tone, the last $2 \mathrm{~s}$ of which coincided with a $0.8 \mathrm{~mA}$ footshock for experiments on PME-1 KO mice, and $1.0 \mathrm{~mA}$ for experiments on LCMT-1 GT mice. After the tone and shock exposure, the mice were left in the conditioning chamber for another $30 \mathrm{~s}$ before returning to their home cages. At $24 \mathrm{~h}$ after their first exposure, animals were returned to the conditioning chamber for $5 \mathrm{~min}$ without footshock or tone presentation. A $\beta$ or vehicle was administered $20 \mathrm{~min}$ before the initial context exposure only.

\section{Open field behavior}

Animals were placed into a Plexiglas arena $(27.3 \mathrm{~cm}$ long $\times 27.3 \mathrm{~cm}$ wide $\times 20.3 \mathrm{~cm}$ high) for $10 \mathrm{~min}$ on each of 2 successive days during which time their movements were tracked using arrays of infrared beams connected to a computerized tracking system, and analyzed using behavioral analysis software (Med Associates). A $\beta$ or vehicle was administered 20 min before testing on each day.

\section{Sensory threshold assessment}

Animals were placed into the same apparatus used for contextual fear conditioning. A sequence of single, $1 \mathrm{~s}$ footshocks were then administered at $30 \mathrm{~s}$ intervals and $0.1 \mathrm{~mA}$ increments from 0 up to a maximum of $0.7 \mathrm{~mA}$. Each animal's behavior was monitored by the experimenter to determine their thresholds for first visible response to the shock (flinch), their first gross motor response (run/ jump), and their first vocalized response. $\mathrm{A} \beta$ or vehicle was administered $20 \mathrm{~min}$ before testing.

\section{Electrophysiological studies}

Extracellular field potential recordings were performed on acute hippocampal slices prepared as described previously (Fa et al., 2010) from heterozygous PME-1 KO and, LCMT-1 GT mice and their WT control siblings. Animals were killed by cervical dislocation, a method of euthanasia approved by the Panel on Euthanasia of the American Veterinary Medical Association that yields viable anestheticfree tissue suitable for electrophysiological recordings. Brains were then rapidly removed and cooled in ice-cold aCSF consisting of the following (in $\mathrm{mM}): 124 \mathrm{NaCl}, 4.4 \mathrm{KCl}, 1 \mathrm{Na}_{2} \mathrm{HPO}_{4}, 25 \mathrm{NaHCO}_{3}$, $2 \mathrm{CaCl}_{2}, 2 \mathrm{MgCl}_{2}$, and 10 glucose. Hippocampi were then dissected and sliced into $400 \mu \mathrm{M}$ sections using a tissue chopper. Slices were incubated at $29^{\circ} \mathrm{C}$ in an interface chamber under continuous perfusion (2 $\mathrm{ml} / \mathrm{min}$ ) with oxygenated aCSF and allowed to recover for a minimum of $90 \mathrm{~min}$ before recording responses in the CA1 region to stimulation of Schaffer collateral projections with a bipolar electrode. Input/output relationships were determined before each recording and stimulus intensities that elicited $30 \%$ of the maximal response were used. Stable baselines were obtained for a minimum of $15 \mathrm{~min}$ before drug or vehicle application and a TBS protocol consisting of three trains separated by $15 \mathrm{~s}$ intervals with each train consisting of 10 bursts at $5 \mathrm{~Hz}$ and each burst consisting of 5 pulses at $100 \mathrm{~Hz}$ was used to elicit LTP.

\section{Western blotting}

Animals were killed by cervical dislocation, an American Veterinary Medical Association-approved method that allows for rapid removal of nonhypoxic brains. Hippocampi were then rapidly dissected, snap frozen in liquid nitrogen, and stored at $-80^{\circ} \mathrm{C}$ before homogenization for Western blot analysis. Hippocampal homogenates were prepared by sonication at $95^{\circ} \mathrm{C}$ in aqueous buffer containing $2 \%$ lithium dodecyl sulfate and $50 \mathrm{~mm}$ Tris, $\mathrm{pH}$ 7.5. Total protein concentrations were determined by bicinchoninic acid assay according to the manufacturer's instructions (Pierce), and $15 \mu \mathrm{g}$ of total protein was loaded per lane on SDS-PAGE gels. Proteins were transferred to PVDF membranes, which were then blocked with Odyssey Blocking Buff (Tris-buffered saline) (LI-COR) for $1 \mathrm{~h}$ at room temperature. Blots were probed with the indicated primary antibodies: [rabbit anti-PME (1:1000) Millipore \#07-095 RRID:AB_310373; mouse anti-LCMT-1 clone 4A4 (1:1000) Cell Signaling \#5691 RRID:AB_10949100; mouse anti-demethyl PP2A/C clone 1D6, (1:1000) Millipore \#05421 RRID:AB_309726; rabbit antiPP2A/C clone 52F8 (1:1000) Cell Signaling \#2259 RRID:AB_561239; rabbit anti -PP2A/A (1:1000) Millipore \#07-250 RRID:AB_310467; mouse anti-PP2A/B55alpha clone 2G9(1:1000) Millipore \#05-592 RRID: AB_309827; mouse anti-phospho-tau clone PHF1(1:500) Peter Davies; mouse anti-phospho-tau clone CP13 (1:500) Peter Davies; rabbit anti- 

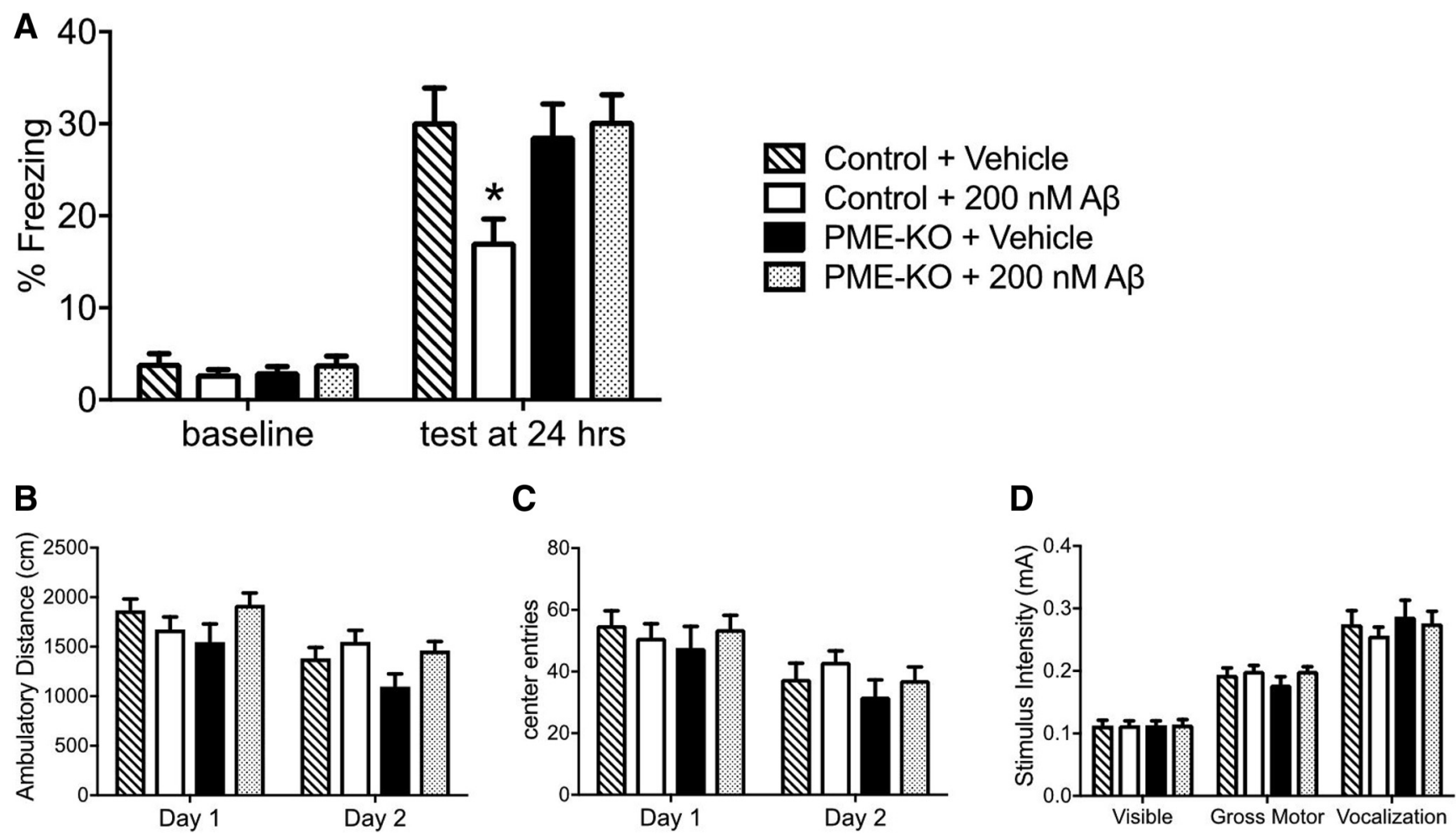

Figure 4. Heterozygous $P M E-K O$ mice are resistant to $A \beta$-induced impairments in contextual fear conditioning. $A$, Plot of average percent of time spent freezing ( \pm SEM) during initial exposure to the training context (baseline) and $24 \mathrm{~h}$ after footshock for the indicated groups. ANOVA for freezing at $24 \mathrm{~h}$ showed a significant difference among groups $\left(F_{(3,70)}=\right.$ 4.424, $p=0.0066)$. Tukey's multiple comparisons show that only the control $+\mathrm{A} \beta$ group was significantly different from all other groups $(p=0.0218$ vs control + vehicle, $p=0.0367$ vs PME-KO + vehicle, and $p=0.0164$ vs PME-KO+A $\beta^{*}$ ). No differences in baseline freezing on day 1 were observed among groups $\left(\right.$ ANOVA: $\left.F_{(3,70)}=0.7894, p=0.5039\right)$. $N=16$ control+vehicle, 20 control $+A \beta, 20$ PME-KO+vehicle, and 18 PME-KO $+A \beta$. B , Plot of average distance traveled $( \pm$ SEM) for the indicated groups during 10 min exposures to an open field environment on subsequent days revealed no significant differences between groups. Two-way repeated-measures ANOVA for distance with day and group as factors shows a significant effect of day $\left(F_{(1,49)}=41.31, p<0.0001\right)$ but not group $\left(F_{(3,49)}=2, p=0.1262\right)$. Pairwise Bonferroni comparisons between groups within a training day revealed no significant differences with $p$ values $<0.05 . N=10$ control + vehicle, 16 control $+\mathrm{A} \beta, 15 \mathrm{PME}+$ vehicle, and $12 \mathrm{PME}+\mathrm{A} \beta$. C, Plot of average number of entries into the center of an open field arena $( \pm S E M)$ for the indicated groups during two 10 min exposures on subsequent days revealed no significant differences between groups. Two-way repeated-measures ANOVA for entries with day and group as factors shows a significant effect of day $\left(F_{(1,49)}=47.28, p<0.0001\right)$ but not group $\left(F_{(3,49)}=0.5627, p=0.6422\right)$. Pairwise Bonferroni comparisons between groups within a training day revealed no significant differences with $p$ values $<0.05 . N=10$ control + vehicle, 16 control $+\mathrm{A} \beta, 15 \mathrm{PME}+\mathrm{vehicle}$, and 12 $\mathrm{PME}+\mathrm{A} \beta$. D, Plot of average threshold for responses to footshocks of increasing intensity for the indicated groups revealed no significant differences in footshock perception (ANOVA for visible response: $F_{(3,79)}=0.0092, p=0.9988$; for gross motor response: $F_{(3,79)}=1.119, p=0.3467$; for vocalization: $\left.F_{(3,79)}=0.4069, p=0.7484\right)$. N $=16$ control+vehicle, 23 control $+\mathrm{A} \beta, 23 \mathrm{PME}+$ vehicle, and $21 \mathrm{PME}+\mathrm{A} \beta$.

tau clone EP2456Y (1:4000) Abcam \#Ab76128 RRID:AB_1524475; mouse anti- $\beta$-actin (1:8000) LI-COR \#926-42 212; rabbit anti- $\beta$-actin (1:8000) Licor \#926-42 210 RRID:AB_1850027] overnight at $4^{\circ} \mathrm{C}$, then washed and incubated with goat anti-rabbit (IRDye 800CW LI-COR) and goat anti-mouse (IRDye 680RD LI-COR) at room temperature for 2 h. For analysis of demethyl and total PP2A/C, blots were first probed with demethyl-specific antibody then stripped for $20 \mathrm{~min}$ at room temp in LI-COR Newblot PVDF stripping buffer (\#928-40 032) plus 0.5\% SDS before reprobing with the total $\mathrm{PP} 2 \mathrm{~A} / \mathrm{C}$ antibody. Immunoreactive bands were detected using an Odyssey imager and analyzed using ImageStudio software (RRID:SCR_013715).

\section{Alkaline demethylation}

Demethylation of PP2A/C was conducted as described by Yu et al. (2001). Homogenates were incubated first for $10 \mathrm{~min}$ in $0.5 \mathrm{M} \mathrm{NaOH}$ at $4^{\circ} \mathrm{C}$, then neutralized by addition of $\mathrm{HCl}$ to a final concentration of 0.5 $\mathrm{mm}$ and Tris, $\mathrm{pH} 6.8$, to final concentration of $0.1 \mathrm{M}$.

\section{A $\beta$ ELISA}

Levels of soluble murine $\mathrm{A} \beta 1-40$ and $\mathrm{A} \beta$ 1-42 were measured in diethylamine-extracted hippocampal homogenates using commercially available ELISA kits (Wako) as described previously (Teich et al., 2013).

\section{Results}

Heterozygous $P M E-K O$ mice exhibit reduced PME-1 protein expression and decreased tau phosphorylation

To examine the effect of reduced PME- 1 expression on $\mathrm{A} \beta$ sensitivity, we used a line of mice described previously that carry a KO mutation in the PME-1 gene (Ortega-Gutierrez et al., 2008). Western blots performed on hippocampal homogenates from mice heterozygous for this mutation showed a $43.4 \pm 0.9 \%$ reduction in PME-1 protein levels compared with WT littermates (Fig. 2A,E). Previous analysis of PP2A/C methylation levels in brains from homozygous embryonic day 18 PME-1 KO mice showed pronounced changes in PP2A/C methylation compared with WT siblings (Ortega-Gutierrez et al., 2008); however, we observed no significant changes in demethyl-PP2A/C levels in hippocampal homogenates from heterozygous $P M E-1 \mathrm{KO}$ mice (Fig. 2B,E). Additional Western blot analysis of LCMT-1 protein in these animals suggested that this was not due to a compensatory decrease in LCMT-1 protein expression (Fig. 2C, $E$ ). Despite the unaltered basal levels of PP2A/C methylation in heterozygous $P M E-1 \mathrm{KO}$ animals, reduced PME-1 expression did result in a $20 \pm 4 \%$ decrease in tau phosphorylation at 

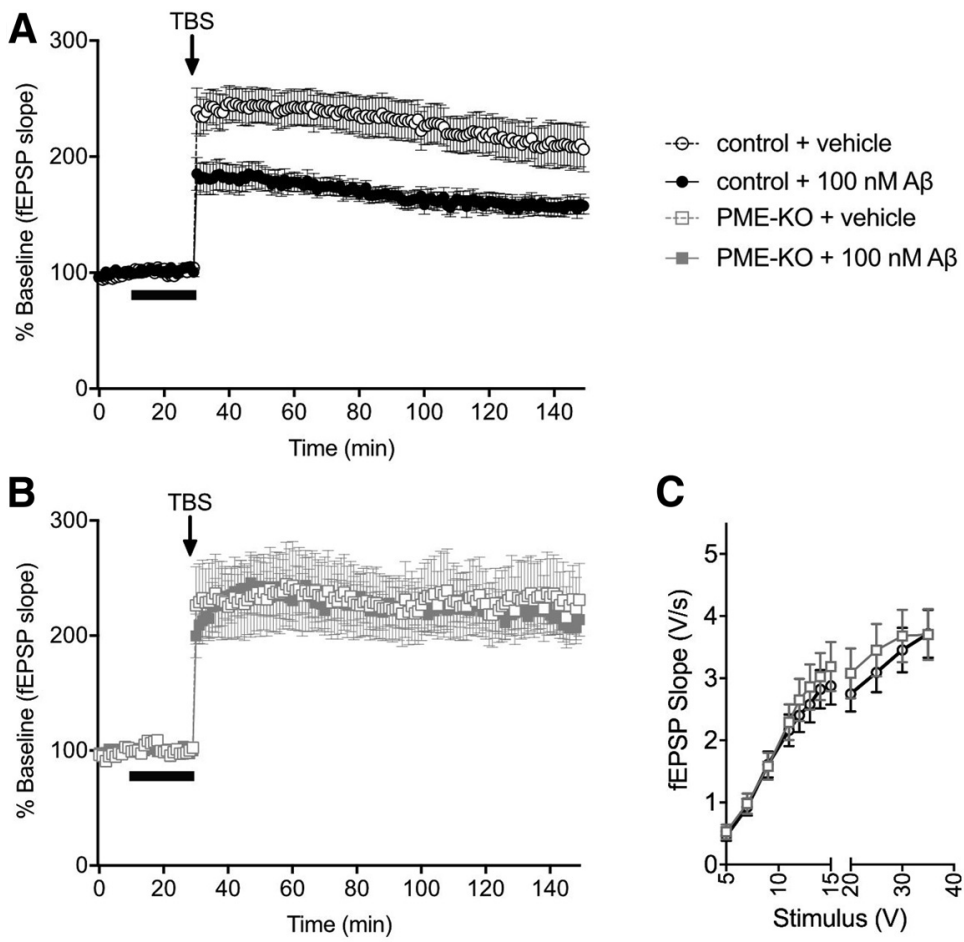

Figure 5. Heterozygous PME-KO mice are resistant to $A \beta$-induced impairments in LTP. $A, B$, Time course of averaged Schaffer collateral fEPSP responses ( \pm SEM) in hippocampal slices prepared from heterozygous PME- 1 KO or WT control mice treated with vehicle or $100 \mathrm{~nm} \mathrm{~A} \beta$ (horizontal bar) 20 min before delivery of TBS (arrow). $A \beta$ treatment significantly reduces potentiated responses following TBS in slices from control mice $(A)$ but not slices from heterozygous PME-1 KO mice $(\boldsymbol{B})$. Two-way repeated-measures ANOVA of last $20 \mathrm{~min}$ for group with time and group as factors shows a significant effect of group $\left(F_{(3,54)}=3.148, p=0.0323\right)$. Fisher's post hoc comparisons show significant differences between: control $+A \beta$ versus control + vehicle $(p=0.0468)$, control $+A \beta$ versus PME $+A \beta(p=0.0124)$ but not $\mathrm{PME}+$ vehicle versus $\mathrm{PME}+\mathrm{A} \beta \quad(p=0.6141)$ or PME + vehicle versus control + vehicle $(p=0.4557) . N=13$ control+vehicle, 14 control $+A \beta, 11 \mathrm{PME}+$ vehicle, and $20 \mathrm{PME}+\mathrm{A} \beta$. C, Plot of stimulus-response relationship ( \pm SEM) at Schaffer collateral synapses in hippocampal slices prepared from heterozygous PME-1 K0 or WT control mice reveals no significant differences between groups (two-way repeated-measures ANOVA for genotype with stimulus intensity and genotype as factors: $\left.F_{(1,89)}=0.1954, p=0.6595\right)$. Data obtained from slices before $A \beta$ treatment and LTP recordings shown in $\boldsymbol{A}$ and in Figure 4A, B. N= 40 control and 51 PME- $1 \mathrm{KO}$.

residues $\mathrm{S} 396 / 404$ that was statistically significant $(p=0.003)$, and a $29 \pm 6 \%$ decrease in tau S202 phosphorylation that was not $(p=0.055)$ (Fig. 2D,E). These changes in tau phosphorylation were not accompanied by significant differences in total tau levels, or PP2A/C, PP2A/A, or PP2A/B $\alpha$ subunit expression between heterozygous PME-1 KO animals and controls (Fig. $2 C-E)$.

\section{Heterozygous $P M E-K O$ mice are resistant to $\mathrm{A} \beta$-induced impairments in a $2 \mathrm{~d}$ radial arm water maze task}

To determine whether reduced PME-1 expression affects the sensitivity of mice to $\mathrm{A} \beta$-induced cognitive impairments, we tested the performance of heterozygous PME-1 KO and WT animals infused with $200 \mathrm{~nm}$ synthetic oligomeric A $\beta$ peptide or vehicle on a $2 \mathrm{~d}$ radial arm water maze task. This test of short-term spatial memory is both hippocampus-dependent and sensitive to acutely elevated A $\beta$ levels (Alamed et al., 2006; Fiorito et al., 2013; Watterson et al., 2013). In this task, animals navigate to an escape platform in a fixed location at the end of one of the maze arms, and the number of errors or wrong-arm entries committed during each block of training trials is used as a measure of their ability to learn and remember its location. Previously, we found that transgenic overexpression of LMCT-1 protected animals from $\mathrm{A} \beta$-induced impairments in this task (Nicholls et al., 2016), and here we observed a similarly protective effect for reduced PME-1 expression in the PME-1 KO heterozygous mice. While administration of $200 \mathrm{~nm} \mathrm{~A} \beta$ significantly impaired the performance of WT animals, the performance of heterozygous PME-1 KO animals was comparable with that of vehicle-treated animals (Fig. $3 A$ ). This improved performance did not appear to result from generally enhanced performance in heterozygous PME-1 KO animals since vehicle-treated heterozygous $P M E-1$ $\mathrm{KO}$ animals performed comparably to vehicle-treated WT controls (Fig. $3 A$ ). To test for potential differences in visual perception, motivation or swimming ability among these groups, we also assessed their performance in a visible platform water maze task, and found no significant differences in either escape latency (Fig. 3B) or swimming speed (Fig. 3C) during four 3-trial training blocks conducted across $2 \mathrm{~d}$, suggesting that differences in these variables do not account for the differences observed among groups in the $2 \mathrm{~d}$ radial arm water maze task.

\section{Heterozygous $P M E-K O$ mice are resistant to $A \beta$-induced impairments in contextual fear conditioning}

As an additional test of the ability of reduced PME-1 expression to protect against $\mathrm{A} \beta$ induced cognitive impairments, we tested $\mathrm{A} \beta$ - and vehicle-treated, heterozygous PME$1 \mathrm{KO}$ and WT animals in a contextual fear conditioning task. This task requires animals to make an association between an aversive footshock and a novel context, and has been found to be both hippocampus-dependent and sensitive to acutely elevated $\mathrm{A} \beta$ levels (Maren et al., 2013; Nicholls et al., 2016). In this task, animals are subjected to a footshock in a novel conditioning chamber, and the amount of time spent freezing during reintroduction to that chamber $24 \mathrm{~h}$ later in the absence of footshock is used to assess their memory for the context in which the aversive stimulus (footshock) was administered. Like the $2 \mathrm{~d}$ radial arm water maze task, this task was also used previously to reveal the protective effects of transgenic LMCT-1 overexpression against $\mathrm{A} \beta$ induced cognitive impairments (Nicholls et al., 2016). Here, we found that $\mathrm{A} \beta$ infusion of WT animals, 20 min before their first exposure to the conditioning chamber significantly reduced freezing responses at $24 \mathrm{~h}$ compared with vehicle-treated controls, whereas, in contrast, $\mathrm{A} \beta$ infusion did not impair the performance of heterozygous PME-1 KO animals (Fig. 4A). These differences were not accompanied by differences in baseline freezing responses or freezing responses between the vehicletreated groups at $24 \mathrm{~h}$, suggesting that reduced PME- 1 expression in the heterozygous PME-1 KO mice prevented the $\mathrm{A} \beta$-induced cognitive impairment that was observed in $\mathrm{A} \beta$ treated WT animals. There were also no significant differences between these groups in their immediate postshock freezing behavior $(30 \mathrm{~s}$ postshock $\%$ freezing \pm SEM: $24.75 \pm 4.83$ control+vehicle, $19.74 \pm 3.63$ control $+\mathrm{A} \beta, 20.99 \pm 3.61$ PME- 1 $\mathrm{KO}+$ vehicle, and $18.14 \pm 4.32 \mathrm{PME}-1 \mathrm{KO}+\mathrm{A} \beta$; ANOVA: 
$\left.F_{(3,70)}=0.4377, p=0.7267\right)$. To test for possible differences in baseline activity levels or anxiety among these groups that might confound our interpretation of their behavior in the contextual fear condition task, we examined their behavior in an open field environment and found no significant differences in ambulatory activity (as assessed by total distance traveled; Fig. 4B) or anxiety (as assessed by entries into the center; Fig. $4 C)$. To test for possible differences in shock perception among these groups that might affect their performance in the contextual fear condition task, we also examined their responses to a range of shock intensities and found comparable thresholds for the first visible, first gross motor, and first vocal response to footshocks of increasing intensity among these groups (Fig. 4D).

\section{Heterozygous $P M E-K O$ mice are resistant to $A \beta$-induced impairments in LTP}

Activity-dependent changes in the efficacy of synaptic transmission are thought to underlie particular forms of learning and memory, and $\mathrm{A} \beta$-induced impairments in synaptic plasticity are thought to contribute to AD-associated behavioral impairments (Ondrejcak et al., 2010). Since our behavioral data suggested that reduced PME-1 expression protects against $\mathrm{A} \beta$-induced cognitive impairments, we sought to determine whether reduced PME-1 expression might also protect against $\mathrm{A} \beta$-induced impairments in synaptic plasticity. To do this, we performed extracellular field potential recordings of LTP at Schaffer collateral synapses in acute hippocampal slice preparations from heterozygous $P M E-1 \mathrm{KO}$ and WT animals. Treatment of WT slices with $100 \mathrm{~nm} \mathrm{~A} \beta 20 \mathrm{~min}$ before administration of a theta-burst stimulus train (TBS) significantly impaired potentiated responses relative to vehicletreated control slices (Fig. 5A), whereas similarly treated slices from heterozygous $P M E-1 \mathrm{KO}$ mice showed no $\mathrm{A} \beta$-induced impairment (Fig. 5B). Potentiated responses in slices from vehicle-treated heterozygous $P M E-1 \mathrm{KO}$ mice were comparable with those in vehicle-treated WT slices (Fig. 5A,B), and a comparison of the slope of evoked responses at increasing stimulus intensities obtained in slices from heterozygous PME-1 KO and WT mice revealed no significant difference in the stimulus-response relationship between these animals (Fig. 5C) that might confound interpretation of these results. Congruent with our previous data on the ability of transgenic LCMT-1 overexpression to protect against $\mathrm{A} \beta$-induced LTP impairment, these data suggest that reduced PME- 1 expression also protects against $\mathrm{A} \beta$-induced impairments in synaptic plasticity, and that this action may underlie its ability to protect against cognitive impairments caused by acute exposure to elevated $\mathrm{A} \beta$ levels.

\section{Heterozygous $P M E-K O$ mice show normal responses to physiological levels of $A \beta$ and produce normal levels of endogenous $A \boldsymbol{\beta}$}

One possible mechanism by which the pathologic effects of exogenously applied $\mathrm{A} \beta$ could be altered in $P M E-1 \mathrm{KO}$ mice is through changes in endogenous $\mathrm{A} \beta$ production. If endogenous $\mathrm{A} \beta$ levels

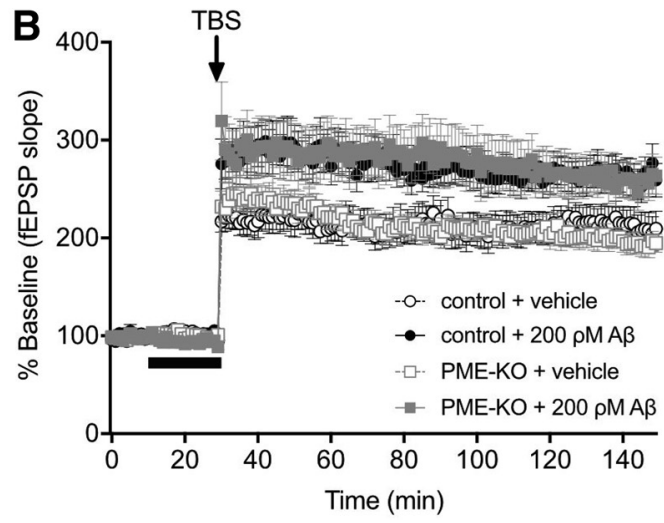

were reduced in these mice, then this could potentially increase the threshold for impairments caused by exogenously applied $\mathrm{A} \beta$. To test this possibility, we measured the levels of soluble endogenous A $\beta 40$ and 42 in hippocampal homogenates prepared from heterozygous PME-1 KO and WT control mice and observed no significant differences between these groups for either peptide (Fig. 6A), suggesting that reduced endogenous $\mathrm{A} \beta$ production does not underlie the effects of reduced PME- 1 expression on $\mathrm{A} \beta$ sensitivity.

In contrast to the cognitive and electrophysiological impairments caused by exposure to nanomolar concentrations of $\mathrm{A} \beta$, treatment of mice or tissue with picomolar concentrations of $\mathrm{A} \beta$ has been found to enhance both cognitive performance and LTP (Puzzo and Arancio, 2013), and these effects are thought to reflect a normal physiological role for $\mathrm{A} \beta$ at nonpathologic concentrations (Puzzo et al., 2008, 2011). To determine whether reduced PME expression might also alter the response to picomolar concentrations of $\mathrm{A} \beta$, we measured theta-burst-evoked LTP at Schaffer collateral synapses in acute hippocampal slices from heterozygous $P M E-1 \mathrm{KO}$ and WT control mice pretreated with either $200 \mathrm{pm}$ oligomeric $\mathrm{A} \beta$ or vehicle. We found that application of 200 pм A $\beta$ significantly enhanced LTP to a similar extent in both WT and heterozygous PME-1 KO animals (Fig. $6 B$ ), suggesting that, while reduced PME-1 expression prevents LTP impairments caused by nanomolar $A \beta$ concentrations, it does not affect the electrophysiological response to picomolar $\mathrm{A} \beta$ concentrations. This selectivity is consistent with our previous observations in PME-1- and LCMT-1-overexpressing transgenic mice (Nicholls et al., 2016) and further supports the notion that this pathway may represent a viable avenue to selectively target the pathologic effects of elevated $\mathrm{A} \beta$ levels without affecting $A \beta$ 's normal physiological functions. The observation that reduced PME-1 expression does not affect picomolar A $\beta$-induced LTP enhancement is also consistent with the normal baseline LTP and behavioral responses we observe in vehicle-treated heterozygous $P M E-1 \mathrm{KO}$ animals and slices (Figs. 3-5). 
A

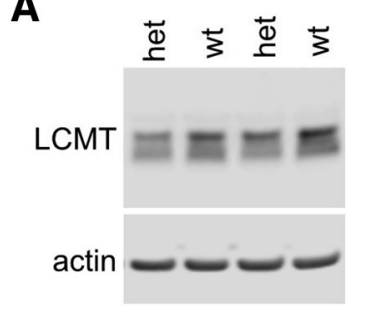

B

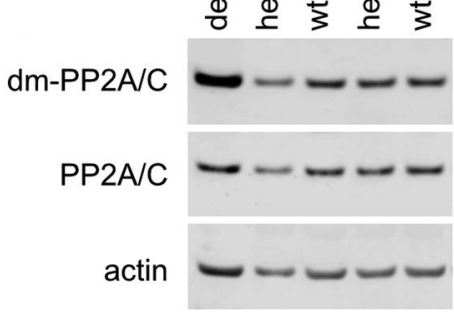

C

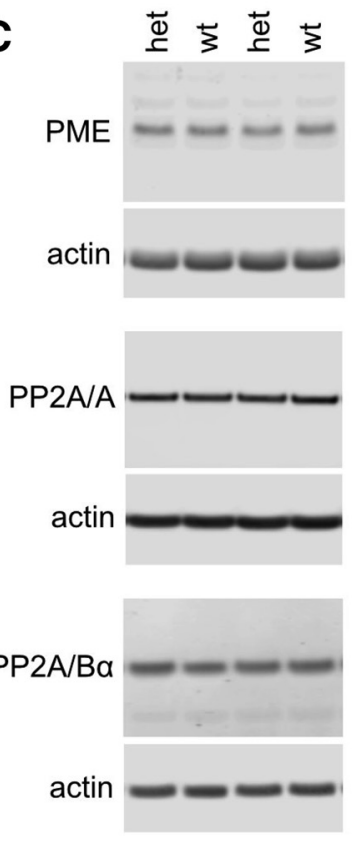

E

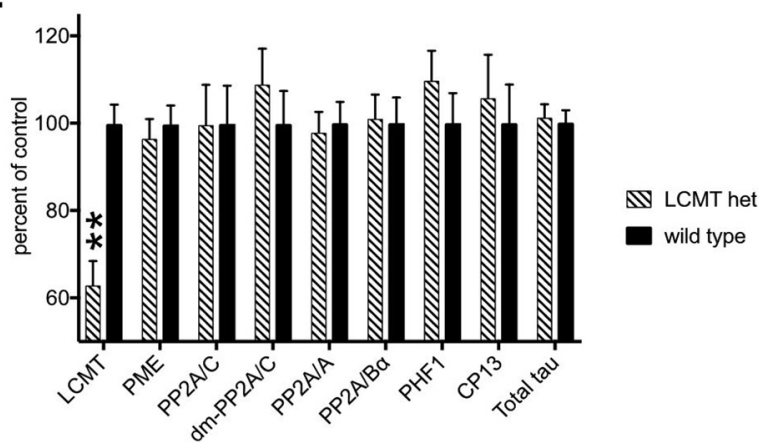

Figure 7. Heterozygous LCMT-GT mice exhibit reduced LCMT-1 protein expression. $\boldsymbol{A}$, Representative Western blot showing anti-LCMT-1 immunoreactivity in hippocampal homogenates from LCMT-1 GT heterozygotes (het) or WT sibling controls together with anti$\beta$-actin immunoreactivity from the same lane as a loading control. $\boldsymbol{B}$, Histogram of mean immunoreactivity ( \pm SEM) for the indicated proteins normalized to within-lane anti- $\beta$-actin immunoreactivity (total PP2A/C immunoreactivity for demethyl-PP2A/C or total tau immunoreactivity for PHF1 and (P13 antibodies) and expressed as percent of mean control value. $\boldsymbol{C}$, Representative Western blot showing anti-demethyl PP2A/C immunoreactivity detected with the $1 D 6$ monoclonal antibody in hippocampal homogenates together with the corresponding anti- $\beta$-actin immunoreactivity and total PP2A/C immunoreactivity detected after stripping and reprobing the same blot. The lane labeled "de-me" contains homogenate treated with $\mathrm{NaOH}$ to demethylate PP2A/C and serve as a positive control for the demethyl-specific anitPP2A/C antibody. D, Representative Western blots showing anti-PP2A/A, PP2A/B $\alpha$, and PME-1 immunoreactivity in hippocampal homogenates from LCMT-1 GT heterozygotes (het) or WT sibling controls together with corresponding same-lane anti- $\beta$-actin immunoreactivity as a loading control. $\boldsymbol{E}$, Representative Western blots showing anti-tau phospho S396/404

\section{Heterozygous LCMT-GT mice exhibit reduced LCMT-1} protein expression

PME-1 and LCMT-1 play opposing roles in regulating PP2A/C methylation, and our previous analysis of PME-1- and LCMT-1overexpressing transgenic mice suggests that these enzymes also have opposing effects on $\mathrm{A} \beta$ sensitivity (Nicholls et al., 2016). Consistent with this view, the data presented above from heterozygous PME-1 KO mice suggest that the effects of reduced PME1 expression are analogous to increased LCMT-1 expression, in that both manipulations decrease sensitivity to cognitive and electrophysiological impairments caused by acute exposure to elevated levels of $\mathrm{A} \beta$. To test this relationship further, we used a previously described line of mice that carry a GT insertion in the LCMT-1 gene (MacKay et al., 2013) to test the prediction that reduced LCMT-1 expression may increase sensitivity to $\mathrm{A} \beta$. Western blot analysis performed on hippocampal homogenates from mice heterozygous for this mutation showed a $37.1 \pm 5.6 \%$ reduction in LCMT-1 protein levels compared with WT littermates (Fig. 7A,E). We obtained no viable homozygous LCMT-1 GT progeny from crosses of heterozygous LCMT-1 GT animals, so heterozygous LCMT-1 GT mice and their WT siblings were used for all experiments. A previous description of PP2A/C methylation levels in brains from homozygous LCMT-1 GT mice reported a 15\% increase in demethylated PP2A/C levels compared with WT siblings (MacKay et al., 2013); however, we observed only an $8.9 \pm 8.2 \%$ increase in demethyl-PP2A/C levels in hippocampal homogenates from heterozygous LCMT-1 GT and WT adult mice that was not statistically significant (Fig. $7 B$, $E)$. The unaltered demethyl-PP2A/C levels in heterozygous LCMT-1 GT mice did not appear to be due to a compensatory decrease in PME-1 protein expression since no differences in PME-1 protein levels were observed in Western blots of these homogenates (Fig. 7C,E). Neither were differences observed between heterozygous LCMT-1 GT and WT siblings in total tau levels, or in $\mathrm{PP} 2 \mathrm{~A} / \mathrm{C}, \mathrm{PP} 2 \mathrm{~A} / \mathrm{A}$, or $\mathrm{PP} 2 \mathrm{~A} / \mathrm{B} \alpha$ subunit expression (Fig. 7C-E). Western blot analysis of tau phosphorylation in heterozygous LCMT-1 GT and WT animals using the phospho-specific PHF1 and CP-13 antibodies showed a $9.7 \pm 6.9 \%$ increase in tau phosphorylation at residues S396/404 and a $5.7 \pm 9.9 \%$ increase in tau phosphorylation at S202, respectively, neither of which reached statistical significance (Fig. $7 D, E)$.

Heterozygous LCMT-GT mice exhibit increased sensitivity to a $\beta$-induced impairments in a $2 \mathbf{d}$ radial arm water maze task To determine whether reduced LCMT-1 expression affects the sensitivity of mice to $\mathrm{A} \beta$-induced cognitive impairments, we tested the performance of heterozygous LCMT-1 GT mice on the $2 \mathrm{~d}$ radial arm water maze task as described above. However, to reveal potential increases in $\mathrm{A} \beta$ sensitivity in heterozygous

\section{$\leftarrow$}

(PHF1) and anti-tau phospho S202 (CP13) together with corresponding total tau immunoreactivity from the same lane, and anti-total tau together with corresponding anti- $\beta$-actin immunoreactivity. All blots were performed on homogenates prepared from 7 heterozygous PME-1 KO animals and 7 WT sibling controls and compared using unpaired $t$ tests: LCMT-1 expression: $t=5.203,{ }^{* *} p=0.0002$, demethyl PP2A/C: $t=0.7975, p=0.4420$, PP2A/C expression: $t=0.2968, p=0.7717$, PP2A/A expression: $t=0.3691, p=0.7185, \mathrm{PP} 2 \mathrm{~A} / \mathrm{B} \alpha$ expression: $t=0.1068, p=0.9167$, PME-1 expression: $t=0.5871, p=0.5680$, PHF1: $t=1, p=0.3370$, (P13: $t=0.431, p=0.6741$, total tau: $t=0.2733, p=0.7892$ ). 
LCMT-1 GT mice, we administered oligomeric $\mathrm{A} \beta$ at a subthreshold dose that did not impair the performance of WT animals. We found that, while the performance of $\mathrm{A} \beta$ treated WT mice was comparable with vehicle-treated controls, $\mathrm{A} \beta$ treatment at this dose did significantly impair the performance of heterozygous LCMT-1 GT animals (Fig. $8 A)$. The LCMT-1 GT mutation alone did not appear to affect performance in this task since vehicle-treated heterozygous LCMT-1 GT animals performed comparably to vehicle-treated WT controls. Neither were any differences observed among groups in either escape latency (Fig. $8 B$ ) or swimming speed (Fig. 8C) during testing in the visible platform water maze task, suggesting that behavior in the radial arm water maze task was not impacted by potential differences in visual perception, motivation, or swimming ability. Together, these data from the $2 \mathrm{~d}$ radial arm and visible platform water maze tasks are consistent with the prediction that reduced LCMT-1 expression increases sensitivity to $\mathrm{A} \beta$-induced $\operatorname{cog}$ nitive impairments.

\section{Heterozygous LCMT-GT mice show increased sensitivity to $A \boldsymbol{\beta}$-induced impairments in contextual fear conditioning}

As an additional test of the effect of reduced LCMT- 1 expression on $\mathrm{A} \beta$-induced cognitive impairments, we tested $\mathrm{A} \beta$ and vehicletreated, heterozygous LCMT-1 GT and WT animals in a contextual fear conditioning task. As in the $2 \mathrm{~d}$ radial arm water maze task above, we infused these animals with $\mathrm{A} \beta$ at a concentration that did not significantly impair the performance of WT control animals, and found that nevertheless this dose significantly impaired the freezing responses of heterozygous LCMT-1 GT animals when tested $24 \mathrm{~h}$ after training (Fig. 9A). The baseline freezing levels before footshock were comparable among these groups (Fig. 9A), and there were no significant differences in their immediate postshock freezing behavior (30 s postshock $\%$ freezing \pm SEM: $9.91 \pm 2.36$ control + vehicle, $10.83 \pm 1.97$ control $+\mathrm{A} \beta, 9.66 \pm 1.54$ LCMT$\mathrm{GT}+$ vehicle, and 9.12 \pm 1.42 LCMT-GT $+\mathrm{A} \beta$; ANOVA: $F_{(3,66)}=$ $0.1536, p=0.9270$ ). Moreover, we found no significant differences in ambulatory activity (as assessed by total distance traveled; Fig. $9 B$ ) or anxiety (as assessed by entries into the center; Fig. 9C) when exposed to an open field environment. To test for possible differences in shock perception among WT and heterozygous LCMT-GT animals treated with vehicle or $\mathrm{A} \beta$, we examined their responses to increasing footshock intensities and found comparable thresholds for the first visible, first gross motor, and first vocal response to footshocks of increasing intensity among all groups (Fig. 9D). The increased sensitivity of heterozygous LCMT-GT animals to A $\beta$ induced impairments in contextual fear conditioning is consistent with the increased sensitivity of these animals to $\mathrm{A} \beta$-induced impairments in the $2 \mathrm{~d}$ radial arm water maze, and with the increased $\mathrm{A} \beta$ sensitivity we observed previously in PME-1-overexpressing transgenic animals (Nicholls et al., 2016).

\section{Heterozygous LCMT-GT mice exhibit increased sensitivity to} A $\beta$-induced LTP impairments

To test the possibility that reduced LCMT-1 expression also increases sensitivity to $\mathrm{A} \beta$-induced impairments in synaptic plasticity, we treated acute hippocampal slices from WT and heterozygous LCMT-GT animals with vehicle or with subthreshold doses of $75 \mathrm{~nm} \mathrm{~A} \beta$ for 20 min before TBS. Potentiated responses in WT slices treated with $\mathrm{A} \beta$ at this concentration were comparable with vehicle-treated controls; however, treatment of heterozygous LCMT-GT slices at this concentration resulted in significantly reduced potentiation relative to both vehicle-treated heterozygous LCMT-GT slices and controls (Fig. 10A,B). A comparison of the slope of evoked responses at increasing stimulus intensities obtained in slices from heterozygous LCMT-GT and WT mice revealed no significant difference in the stimulusresponse relationship between these groups (Fig. 10C) that might confound interpretation of these results. Together, these results 


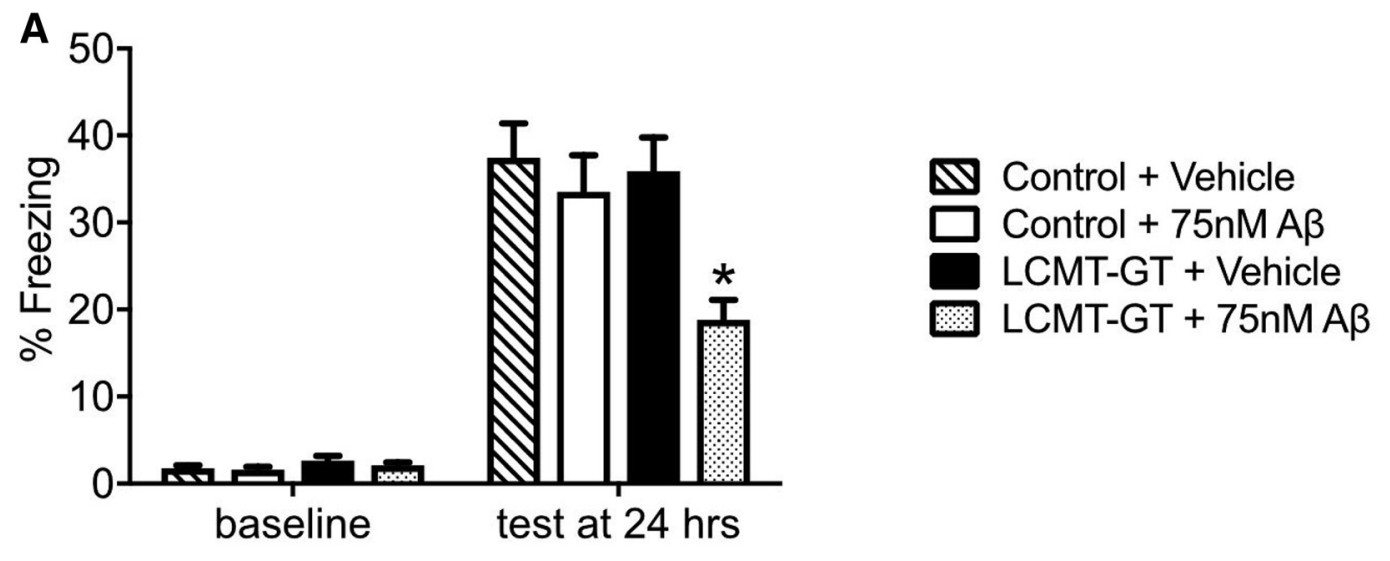

B

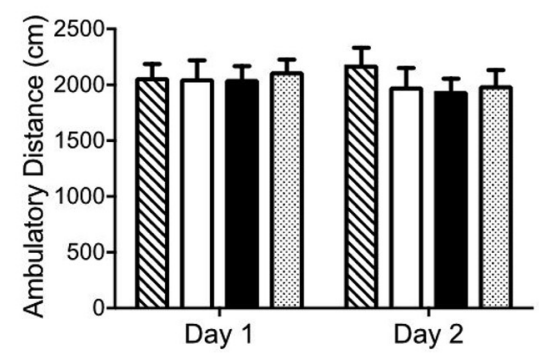

C

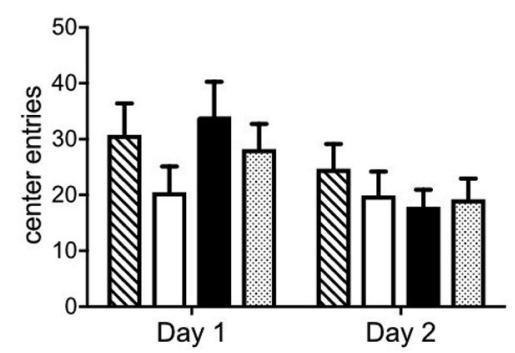

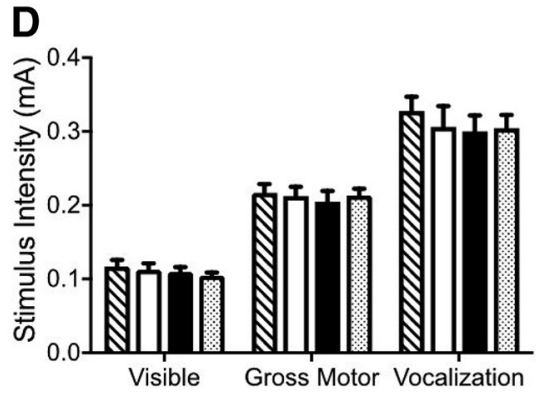

Figure 9. Reduced LCMT-1 expression increases sensitivity to $A \beta$-induced impairments in contextual fear conditioning. $A$, Plot of average percent of time spent freezing ( \pm SEM) during initial exposure to the training context (baseline) and $24 \mathrm{~h}$ after footshock for the indicated groups. ANOVA for freezing at $24 \mathrm{~h}$ showed a significant difference among groups $\left(F_{(3,66)}=5.932\right.$, $p=0.0012)$. Tukey's multiple comparisons show that only the LCMT $+\mathrm{A} \beta$ group was significantly different from vehicle-treated controls $\left({ }^{*} p=0.0015\right)$, and that the LCMT $+\mathrm{A} \beta$ group was also significantly different from $A \beta$-treated controls $(p=0.0272)$. No differences in baseline freezing on day 1 were observed among groups (ANOVA: $\left.F_{(3,66)}=1.284, p=0.2873\right)$. $N=16$ control + vehicle, 16 control $+A \beta, 19$ LCMT-GT + vehicle, and 19 LCMT-GT + A $\beta$. B, Plot of average distance traveled ( \pm SEM) for the indicated groups during 10 min exposures to an open field environment on subsequent days revealed no significant differences between groups. Two-way repeated-measures ANOVA for distance with day and group as factors showed no significant effect of day $\left(F_{(1,44)}=1.284, p=0.2634\right)$ or group $\left(F_{(3,44)}=0.1835, p=0.9070\right)$. Pairwise Bonferroni comparisons between groups within a training day revealed no significant differences with $p$ values $<0.05 . N=10$ control+vehicle, 9 control $+A \beta, 13$ LCMT-GT + vehicle, and 16 LCMT-GT + A $\beta$. C, Plot of average number of entries into the center of an open field arena ( \pm SEM) for the indicated groups during two 10 min exposures on subsequent days revealed no significant differences between groups. Two-way repeated-measures ANOVA for entries with day and group as factors shows a significant effect of day $\left(F_{(1,54)}=7.45, p=0.0085\right)$ but not group $\left(F_{(3,54)}=0.6784, p=0.5691\right)$. Pairwise Bonferroni comparisons between groups within a training day revealed no significant differences with $p$ values $<0.05 . N=10$ control + vehicle, 9 control $+A \beta, 13$ LCMT-GT + vehicle, and 16 LCMT-GT + A $\beta$. D, Plot of average threshold for responses to footshocks of increasing intensity for the indicated groups revealed no significant differences in footshock perception (ANOVA for visible response: $F_{(3,74)}=0.5746, p=0.6335$; for gross motor response: $F_{(3,74)}=0.1716, p=0.91523$; for vocalization: $\left.F_{(3,74)}=0.3167, p=0.8133\right)$. $N=18$ control + vehicle, 16 control $+\mathrm{A} \beta, 21$ $\mathrm{LCMT}-\mathrm{GT}+$ vehicle, and $23 \mathrm{LCMT}-\mathrm{GT}+\mathrm{A} \beta$.

suggest that reduced LCMT-1 expression increases sensitivity to A $\beta$-induced LTP impairments, and that these impairments in synaptic plasticity may underlie the increased sensitivity of these animals to $\mathrm{A} \beta$-induced cognitive impairments.

\section{Discussion}

Our data show that mice with reduced PME-1 expression as a result of a heterozygous PME-1 KO mutation were resistant to cognitive impairments caused by acute exposure to synthetic oligomeric $\mathrm{A} \beta$ preparations in both a $2 \mathrm{~d}$ radial arm water maze and a contextual fear conditioning task. We also found that reduced PME- 1 expression prevented $\mathrm{A} \beta$-induced impairments of LTP in acute hippocampal slice preparations from these animals, suggesting that reduced PME-1 expression may protect against $\mathrm{A} \beta$-induced cognitive impairments by preventing the impairments in synaptic plasticity that are thought to underlie them. These protective effects of reduced PME-1 expression are consistent with previously described experiments in which we found that transgenic overexpression of PME-1-sensitized mice to $\mathrm{A} \beta$-induced impairments, whereas overexpression of LCMT- 1 protected against A $\beta$-induced impairments (Nicholls et al., 2016). In addition, we found that reduced PME-1 expression in heterozygous $P M E-1 \mathrm{KO}$ mice did not significantly affect endogenous $\mathrm{A} \beta$ levels, LTP enhancement by picomolar $\mathrm{A} \beta$ exposure, or baseline behavioral or electrophysiological responses. Together, these data argue that the effect of reduced PME-1 expression on $\mathrm{A} \beta$ sensitivity is selective for impairments caused by pathologically elevated concentrations of $\mathrm{A} \beta$, but does not interfere with normal physiological $\mathrm{A} \beta$ functions. This interpretation is also consistent with our data from PME-1- and LCMT-1-overexpressing transgenic mice where we saw altered sensitivity to nanomolar $\mathrm{A} \beta$ exposure but no evidence for effects on picomolar $\mathrm{A} \beta$ sensitivity or endogenous $\mathrm{A} \beta$ production (Nicholls et al., 2016).

The antagonistic relationship that exists between the biochemical activities of PME-1 and LCMT-1, as well as our previous data on the effects of PME-1 and LCMT-1 overexpression (Nicholls et al., 2016), suggest that reduced LCMT-1 expression should increase sensitivity to $\mathrm{A} \beta$-induced impairments, and this is what we observed when we treated LCMT-1 GT mice with subthreshold doses of $\mathrm{A} \beta$ that did not elicit impairments in WT controls. We found that reduced LCMT-1 expression resulted in increased sensitivity to $\mathrm{A} \beta$-induced cognitive impairments in 
the $2 \mathrm{~d}$ radial arm water maze and contextual fear conditioning tasks, as well as increased sensitivity to $\mathrm{A} \beta$-induced LTP impairments. These effects are consistent with the opposing biochemical functions of LCMT-1 and PME-1, the effect of reduced PME-1 expression reported here, and our previous data on the effects of transgenic PME-1 and LCMT-1 overexpression (Nicholls et al., 2016).

The fact that reduced PME-1 expression selectively protects against impairments caused by nanomolar concentrations of $\mathrm{A} \beta$ without interfering with normal physiological $\mathrm{A} \beta$ functions suggests that high concentrations of $\mathrm{A} \beta$ produce impairments via a pathway that is sensitive to reduced PME-1 expression, whereas low physiological concentrations of $\mathrm{A} \beta$ act via a pathway that is independent from, or less sensitive to, reduced PME-1 expression. Our current hypothesis for the mechanism by which reduced PME- 1 expression affects $\mathrm{A} \beta$ sensitivity is that reduced PME-1 expression acts via PP2A to increase tau dephosphorylation and reduce the pathologic response to nanomolar concentrations of $\mathrm{A} \beta$. This model is consistent with published data showing that PME-1 regulates PP2A activity and subunit assembly (Sents et al., 2013; Kaur and Westermarck, 2016), that PP2A acts as the principal tau phosphatase (Sontag and Sontag, 2014), and that tau acts downstream of $\mathrm{A} \beta$ to contribute to $\mathrm{A} \beta$ induced impairments (Bloom, 2014; SpiresJones and Hyman, 2014). This model is also consistent with the decreased levels of tau phosphorylation that we found in the heterozygous PME-1 KO mice. However, in our experiments, we did not observe a significant increase in basal levels of PP2A methylation in the heterozygous PME-1 KO mice that would have been consistent with reduced PME-1 expression acting through PP2A methylation to exert its protective effects. Instead, this result raises the possibility that reduced PME-1 expression may act on PP2A via a methylationindependent mechanism, such as reduced binding to PP2A or its subunits that could alter PP2A stability, assembly, activity, or substrate interactions (Kaur and Westermarck, 2016). It is also possible that other PME-1 targets, such as the related phosphatases, PP4 and PP6 (Hwang et al., 2016), may mediate the protective effects of reduced PME-1 expression.

Published data suggest that PME-1 plays a largely inhibitory role in regulating PP2A (Sents et al., 2013; Kaur and Westermarck, 2016), and so the effect of reduced PME-1 expression on $\mathrm{A} \beta$ sensitivity that we describe here is consistent with reports of the protective effects of $\mathrm{PP} 2 \mathrm{~A}$ activators in other AD models. These include sodium selenate, a PP2A activator that has been shown to reduce tau phosphorylation and cognitive impairments in mouse tauopathy models (Corcoran et al., 2010; van Eersel et al., 2010) and is being pursued in early clinical trials as a potential AD therapeutic (Cardoso et al., 2019); COG1410, an ApoE peptide mimetic that activates PP2A by inhibiting the PP2A inhibitor, SET/I2, and protects against impairments in a mouse $\mathrm{AD}$ model (Vitek et al., 2012); and FTY720/fingolimod, an immunosuppressant compound used in the treatment of multiple sclerosis that also protects against $\mathrm{A} \beta$-induced impairments (Fukumoto et al., 2014; Joshi et al., 2017) and was subsequently found to activate PP2A in addition to acting on other targets (Cristóbal et al., 2016). A potential obstacle for therapeutic approaches that target PP2A, however, stems from the large number of PP2A isoforms and substrates that exist and concern over a lack of specificity that might result from broad PP2A activation. The data we present here suggest that it may be possible to develop PP2A-based therapies for AD using PME-1 inhibitors to selectively alter the activity of $\mathrm{PP} 2 \mathrm{~A}$ isoforms that are regulated by demethylation (Longin et al., 2007; Xu et al., 2008). One candidate in this regard is eicosanoyl-5-hydroxytryptamide, which was identified in a screen for naturally occurring compounds that inhibit PP2A demethylation (K. W. Lee et al., 2011) and subsequently found to reduce $\mathrm{AD}$-related impairments in rats that overexpress an endogenous PP2A inhibitor (BasurtoIslas et al., 2014), and to protect against $\mathrm{A} \beta$-induced impairments in experiments similar to those described here (Asam et al., 2017). Additionally, two other small-molecule inhibitors of PME-1 have been identified that may represent viable starting points from which to pursue this approach (Bachovchin et al., 2011a,b). However, additional research will be required to explore further the efficacy of these and other PME-1 inhibitors 
and realize the therapeutic potential of this pathway for the treatment of Alzheimer's disease and other disorders.

\section{References}

Alamed J, Wilcock DM, Diamond DM, Gordon MN, Morgan D (2006) Two-day radial-arm water maze learning and memory task: robust resolution of amyloid-related memory deficits in transgenic mice. Nat Protoc 1:1671-1679.

Asam K, Staniszewski A, Zhang H, Melideo SL, Mazzeo A, Voronkov M, Huber KL, Perez E, Stock M, Stock JB, Arancio O, Nicholls RE (2017) Eicosanoyl-5-hydroxytryptamide (EHT) prevents Alzheimer's diseaserelated cognitive and electrophysiological impairments in mice exposed to elevated concentrations of oligomeric beta-amyloid. PLoS One 12: e0189413.

Bachovchin DA, Zuhl AM, Speers AE, Wolfe MR, Weerapana E, Brown SJ, Rosen H, Cravatt BF (2011a) Discovery and optimization of sulfonyl acrylonitriles as selective, covalent inhibitors of protein phosphatase methylesterase-1. J Med Chem 54:5229-5236.

Bachovchin DA, Mohr JT, Speers AE, Wang C, Berlin JM, Spicer TP, Fernandez-Vega V, Chase P, Hodder PS, Schurer SC, Nomura DK, Rosen H, Fu GC, Cravatt BF (2011b) Academic cross-fertilization by public screening yields a remarkable class of protein phosphatase methylesterase-1 inhibitors. Proc Natl Acad Sci USA 108:6811-6816.

Basurto-Islas G, Blanchard J, Tung YC, Fernandez JR, Voronkov M, Stock M, Zhang S, Stock JB, Iqbal K (2014) Therapeutic benefits of a component of coffee in a rat model of Alzheimer's disease. Neurobiol Aging 35:2701-2712.

Bloom GS (2014) Amyloid-beta and tau: the trigger and bullet in Alzheimer disease pathogenesis. JAMA Neurol 71:505-508.

Bolognin S, Blanchard J, Wang X, Basurto-Islas G, Tung YC, Kohlbrenner E, Grundke-Iqbal I, Iqbal K (2012) An experimental rat model of sporadic Alzheimer's disease and rescue of cognitive impairment with a neurotrophic peptide. Acta Neuropathol 123:133-151.

Cardoso BR, Roberts BR, Malpas CB, Vivash L, Genc S, Saling MM, Desmond P, Steward C, Hicks RJ, Callahan J, Brodtmann A, Collins S, Macfarlane S, Corcoran NM, Hovens CM, Velakoulis D, O'Brien TJ, Hare DJ, Bush AI (2019) Supranutritional sodium selenate supplementation delivers selenium to the central nervous system: results from a randomized controlled pilot trial in Alzheimer's disease. Neurotherapeutics 16:192-202.

Corcoran NM, Martin D, Hutter-Paier B, Windisch M, Nguyen T, Nheu L, Sundstrom LE, Costello AJ, Hovens CM (2010) Sodium selenate specifically activates PP2A phosphatase, dephosphorylates tau and reverses memory deficits in an Alzheimer's disease model. J Clin Neurosci 17:1025-1033.

Cristóbal I, Madoz-Gúrpide J, Manso R, González-Alonso P, Rojo F, GarcíaFoncillas J (2016) Potential anti-tumor effects of FTY720 associated with PP2A activation: a brief review. Curr Med Res Opin 32:1137-1141.

Fa M, Orozco IJ, Francis YI, Saeed F, Gong Y, Arancio O (2010) Preparation of oligomeric beta-amyloid 1-42 and induction of synaptic plasticity impairment on hippocampal slices. J Vis Exp 41:1884.

Fiorito J, Saeed F, Zhang H, Staniszewski A, Feng Y, Francis YI, Rao S, Thakkar DM, Deng SX, Landry DW, Arancio O (2013) Synthesis of quinoline derivatives: discovery of a potent and selective phosphodiesterase 5 inhibitor for the treatment of Alzheimer's disease. Eur J Med Chem 60:285-294.

Fukumoto K, Mizoguchi H, Takeuchi H, Horiuchi H, Kawanokuchi J, Jin S, Mizuno T, Suzumura A (2014) Fingolimod increases brain-derived neurotrophic factor levels and ameliorates amyloid beta-induced memory impairment. Behav Brain Res 268:88-93.

Gong CX, Singh TJ, Grundke-Iqbal I, Iqbal K (1993) Phosphoprotein phosphatase activities in Alzheimer disease brain. J Neurochem 61:921-927.

Gong CX, Shaikh S, Wang JZ, Zaidi T, Grundke-Iqbal I, Iqbal K (1995) Phosphatase activity toward abnormally phosphorylated tau: decrease in Alzheimer disease brain. J Neurochem 65:732-738.

Hwang J, Lee JA, Pallas DC (2016) Leucine carboxyl methyltransferase 1 (LCMT-1) methylates protein phosphatase 4 (PP4) and protein phosphatase 6 (PP6) and differentially regulates the stable formation of different PP4 holoenzymes. J Biol Chem 291:21008-21019.

Joshi P, Gabrielli M, Ponzoni L, Pelucchi S, Stravalaci M, Beeg M, Mazzitelli S, Braida D, Sala M, Boda E, Buffo A, Gobbi M, Gardoni F, Matteoli M,
Marcello E, Verderio C (2017) Fingolimod limits acute Abeta neurotoxicity and promotes synaptic versus extrasynaptic NMDA receptor functionality in hippocampal neurons. Sci Rep 7:41734.

Kaur A, Westermarck J (2016) Regulation of protein phosphatase 2A (PP2A) tumor suppressor function by PME-1. Biochem Soc Trans 44:1683-1693.

Kins S, Crameri A, Evans DR, Hemmings BA, Nitsch RM, Gotz J (2001) Reduced protein phosphatase $2 \mathrm{~A}$ activity induces hyperphosphorylation and altered compartmentalization of tau in transgenic mice. J Biol Chem 276:38193-38200.

Lee KW, Chen W, Junn E, Im JY, Grosso H, Sonsalla PK, Feng X, Ray N, Fernandez JR, Chao Y, Masliah E, Voronkov M, Braithwaite SP, Stock JB, Mouradian MM (2011) Enhanced phosphatase activity attenuates alphasynucleinopathy in a mouse model. J Neurosci 31:6963-6971.

Lee L, Kosuri P, Arancio O (2014) Picomolar amyloid-beta peptides enhance spontaneous astrocyte calcium transients. J Alzheimers Dis 38:49-62.

Longin S, Zwaenepoel K, Louis JV, Dilworth S, Goris J, Janssens V (2007) Selection of protein phosphatase $2 \mathrm{~A}$ regulatory subunits is mediated by the $\mathrm{C}$ terminus of the catalytic subunit. J Biol Chem 282:26971-26980.

Louis JV, Martens E, Borghgraef P, Lambrecht C, Sents W, Longin S, Zwaenepoel K, Pijnenborg R, Landrieu I, Lippens G, Ledermann B, Gotz J, Van Leuven F, Goris J, Janssens V (2011) Mice lacking phosphatase PP2A subunit PR61/B' delta (Ppp2r5d) develop spatially restricted tauopathy by deregulation of CDK5 and GSK3beta. Proc Natl Acad Sci USA 108:6957-6962.

MacKay KB, Tu Y, Young SG, Clarke SG (2013) Circumventing embryonic lethality with Lcmtl deficiency: generation of hypomorphic Lcmtl mice with reduced protein phosphatase $2 \mathrm{~A}$ methyltransferase expression and defects in insulin signaling. PLoS One 8:e65967.

Maren S, Phan KL, Liberzon I (2013) The contextual brain: implications for fear conditioning, extinction and psychopathology. Nat Rev Neurosci $14: 417-428$.

Martin L, Latypova X, Wilson CM, Magnaudeix A, Perrin ML, Terro F (2013) Tau protein phosphatases in Alzheimer's disease: the leading role of PP2A. Ageing Res Rev 12:39-49.

Nicholls RE, Sontag JM, Zhang H, Staniszewski A, Yan S, Kim CY, Yim M, Woodruff CM, Arning E, Wasek B, Yin D, Bottiglieri T, Sontag E, Kandel ER, Arancio O (2016) PP2A methylation controls sensitivity and resistance to beta-amyloid-induced cognitive and electrophysiological impairments. Proc Natl Acad Sci USA 113:3347-3352.

Ondrejcak T, Klyubin I, Hu NW, Barry AE, Cullen WK, Rowan MJ (2010) Alzheimer's disease amyloid beta-protein and synaptic function. Neuromolecular Med 12:13-26.

Ortega-Gutierrez S, Leung D, Ficarro S, Peters EC, Cravatt BF (2008) Targeted disruption of the PME-1 gene causes loss of demethylated PP2A and perinatal lethality in mice. PLoS One 3:e2486.

Paxinos G, Franklin KB (2013) Paxinos and Franklin's the mouse brain in stereotaxic coordinates, Ed 4. Amsterdam: Elsevier.

Puzzo D, Arancio O (2013) Amyloid-beta peptide: Dr. Jekyll or Mr. Hyde? J Alzheimers Dis 33 Suppl 1:S111-S120.

Puzzo D, Privitera L, Leznik E, Fa M, Staniszewski A, Palmeri A, Arancio O (2008) Picomolar amyloid-beta positively modulates synaptic plasticity and memory in hippocampus. J Neurosci 28:14537-14545.

Puzzo D, Privitera L, Fa M, Staniszewski A, Hashimoto G, Aziz F, Sakurai M, Ribe EM, Troy CM, Mercken M, Jung SS, Palmeri A, Arancio O (2011) Endogenous amyloid-beta is necessary for hippocampal synaptic plasticity and memory. Ann Neurol 69:819-830.

Schild A, Ittner LM, Gotz J (2006) Altered phosphorylation of cytoskeletal proteins in mutant protein phosphatase $2 \mathrm{~A}$ transgenic mice. Biochem Biophys Res Commun 343:1171-1178.

Sents W, Ivanova E, Lambrecht C, Haesen D, Janssens V (2013) The biogenesis of active protein phosphatase $2 \mathrm{~A}$ holoenzymes: a tightly regulated process creating phosphatase specificity. FEBS J 280:644-661.

Sontag E, Luangpirom A, Hladik C, Mudrak I, Ogris E, Speciale S, White CL (2004) Altered expression levels of the protein phosphatase 2A ABalphaC enzyme are associated with Alzheimer disease pathology. J Neuropathol Exp Neurol 63:287-301.

Sontag JM, Sontag E (2014) Protein phosphatase 2A dysfunction in Alzheimer's disease. Front Mol Neurosci 7:16.

Spires-Jones TL, Hyman BT (2014) The intersection of amyloid beta and tau at synapses in Alzheimer's disease. Neuron 82:756-771. 
Stine WB Jr, Dahlgren KN, Krafft GA, LaDu MJ (2003) In vitro characterization of conditions for amyloid-beta peptide oligomerization and fibrillogenesis. J Biol Chem 278:11612-11622.

Sun L, Liu SY, Zhou XW, Wang XC, Liu R, Wang Q, Wang JZ (2003) Inhibition of protein phosphatase $2 \mathrm{~A}$ - and protein phosphatase 1induced tau hyperphosphorylation and impairment of spatial memory retention in rats. Neuroscience 118:1175-1182.

Teich AF, Patel M, Arancio O (2013) A reliable way to detect endogenous murine beta-amyloid. PLoS One 8:e55647.

Van der Jeugd A, Parra-Damas A, Baeta-Corral R, Soto-Faguás CM, Ahmed T, LaFerla FM, Giménez-Llort L, D’Hooge R, Saura CA (2018) Reversal of memory and neuropsychiatric symptoms and reduced tau pathology by selenium in 3xTg-AD mice. Sci Rep 8:6431.

van Eersel J, Ke YD, Liu X, Delerue F, Kril JJ, Gotz J, Ittner LM (2010) Sodium selenate mitigates tau pathology, neurodegeneration, and functional deficits in Alzheimer's disease models. Proc Natl Acad Sci USA 107:13888-13893.

Vitek MP, Christensen DJ, Wilcock D, Davis J, Van Nostrand WE, Li FQ, Colton CA (2012) APOE-mimetic peptides reduce behavioral deficits, plaques and tangles in Alzheimer's disease transgenics. Neurodegener Dis 10:122-126.

Vogelsberg-Ragaglia V, Schuck T, Trojanowski JQ, Lee VM (2001) PP2A mRNA expression is quantitatively decreased in Alzheimer's disease hippocampus. Exp Neurol 168:402-412.
Wang X, Blanchard J, Kohlbrenner E, Clement N, Linden RM, Radu A, Grundke-Iqbal I, Iqbal K (2010) The carboxy-terminal fragment of inhibitor-2 of protein phosphatase-2A induces Alzheimer disease pathology and cognitive impairment. FASEB J 24:4420-4432.

Wang Y, Mandelkow E (2016) Tau in physiology and pathology. Nat Rev Neurosci 17:5-21.

Watterson DM, Grum-Tokars VL, Roy SM, Schavocky JP, Bradaric BD, Bachstetter AD, Xing B, Dimayuga E, Saeed F, Zhang H, Staniszewski A, Pelletier JC, Minasov G, Anderson WF, Arancio O, Van Eldik LJ (2013) Development of novel chemical probes to address CNS protein kinase involvement in synaptic dysfunction. PLoS One 8:e66226.

Xu Y, Chen Y, Zhang P, Jeffrey PD, Shi Y (2008) Structure of a protein phosphatase 2A holoenzyme: insights into B55-mediated Tau dephosphorylation. Mol Cell 31:873-885.

Yin YY, Liu H, Cong XB, Liu Z, Wang Q, Wang JZ, Zhu LQ (2010) Acetyl-Lcarnitine attenuates okadaic acid induced tau hyperphosphorylation and spatial memory impairment in rats. J Alzheimers Dis 19:735-746.

Yu XX, Du X, Moreno CS, Green RE, Ogris E, Feng Q, Chou L, McQuoid MJ, Pallas DC (2001) Methylation of the protein phosphatase 2A catalytic subunit is essential for association of Balpha regulatory subunit but not SG2NA, striatin, or polyomavirus middle tumor antigen. Mol Biol Cell 12:185-199.

Zhuo JM, Wang H, Pratico D (2011) Is hyperhomocysteinemia an Alzheimer's disease (AD) risk factor, an $\mathrm{AD}$ marker, or neither? Trends Pharmacol Sci 32:562-571. 